Hamzeh, F.R, and Albanna, R.M, (2019). "Developing a Tool to Assess and Enhance the Workers' Understanding of Lean Concepts of Construction." In: Proc. $27^{\text {th }}$ Annual Conference of the International. Group for Lean Construction (IGLC), Pasquire C. and Hamzeh F.R. (ed.), Dublin, Ireland, pp. 179-190. DOI: https://doi.org/10.24928/2019/0241. Available at: 〈www.iglc.net>.

\title{
DEVELOPING A TOOL TO ASSESS WORKERS' UNDERSTANDING OF LEAN CONCEPTS IN CONSTRUCTION
}

\author{
Hamzeh, F.R. ${ }^{1}$, and Albanna,R.M ${ }^{2}$
}

\begin{abstract}
In order to reap the benefits of Lean Construction, construction companies should integrate, empower and enable all personnel involved in the construction process whether on or off site. As such, construction workers need to be trained on lean construction concepts and principles. The purpose of this paper is to develop a tool to assess the workers' understanding of Lean concepts in construction. In this paper, the lean construction concepts are categorized into eight main areas: planning and control, standardization, pull production, wastes, kaizen, site organization, quality and safety. A lean construction worker knowledge profile was formulated based on the aforementioned categories. This profile encompasses all the knowledge, information, and lean background that a construction worker should distinguish, utilize and harness on the construction site. This lean profile formed the basis for a survey tool conducted on different construction sites in Lebanon to test its efficacy in identification areas of weaknesses in understanding lean principles as the lever of consruciton workers. Out of the eight categories, the workers lacked mainly the required acquaintance in pull production and waste. As a result, training exercises and games are recommended to instill lean construction concepts in the everyday behaviour, practice and job performance of construction workers.
\end{abstract}

\section{KEYWORDS}

Lean construction, construction workers, training games.

\section{INTRODUCTION AND LITERATURE REVIEW}

Lean construction is a philosophy that is based on waste reduction and continuous improvement (Koskela, 1992). Lean culture focuses on people, teams and partners facilitating change in the way they think, behave and execute their work (Liker, 2004).

Construction workers play a significant role in the implementation of lean construction principles and methods. Lean construction mandates workers' active participation in the

\footnotetext{
${ }^{1}$ Associate Professor, Civil and Environmental Engineering Dept., University of Alberta, Canada, hamzeh@ualberta.ca

${ }^{2}$ Graduate Student, Civil and Environmental Engineering Department, American University of Beirut, Beirut, Lebanon, rma138@mail.aub.edu
} 
construction process stipulating new roles and responsibilities for construction workers which neccesitates being qualified in lean tools, concepts and principles, which include: first, the inclusion of workers in developing the work plan; second, reliable promises, coordination and active communication between the construction workers themselves and between the construction workers and foremen; and third, the continuous improvement through reflecting upon mistakes, finding root causes and taking preventive actions (Ballard, 2000). Unfortunately, this is not always happening. For example, while studying a large project in Brazil, one of the obstacles faced was to promote the compliance of the lean construction concepts and tools among field employees such as: foremen, crew leaders, and construction workers (Barbosa et al. 2013).

Lean implementation has has been a challenge due to many organizational and human factors related to workers, such as: weak communication and lack of transparency, poor involvement of the construction workers, inadequate preparation and training of participants and lack of role definition (Brady et al. 2011). In a recent case study addressing the implementation of Lean and Last Planner System implementation on a construction project in Beirut, Lebanon, it was confirmed that one of the main challenges was a lack of personnel training and employee resistance to change (Hamzeh et al., 2016).

Accordingly, to effectively implement lean tools, concepts and methods, Guerrero and Sire (2001) suggested training as one of the best ways to enhance, change and positively affect the workers' performance, improve their productivity, and augment the quality of the delivered work. There are many research studies that focus on teaching, providing training, workshops, and courses on lean-related topics for students, engineers and middle managers both at universities and in companies (Tsao et al. 2012). A recent study by Zanotti et al. (2017) conducted a training program targeting one aspect of lean construction which is waste identification using the A3 tool. However, there is limited research that addresses the construction understanding and application of lean concepts in construction.

Thus this paper aims to developing a tool to assess workers' insights of lean concepts in construction and include: developing a questionnaire which addresses the different lean construction categories that need to be comprehended by construction workers, testing the assessment questionnaire in Lebanon, pinpointing the areas of weaknesses construction workers have regarding lean construction concepts, and finally enumerating the training exercises that can be exploited to backfill these gaps.

\section{METHODOLOGY}

A thorough literature review was conducted to establish a holistic understanding of all lean concepts that construction workers should know. The categories were selected based on the level of understanding of the construction workers for lean concepts, their roles and responsibilities in lean construction in addition to what they should know and apply in construction sites.

The lean concepts were categorized into seven areas: standardization, pull production, waste, aizen, site organization, quality, planning and control. Based on these eight categories, a lean worker knowledge profile was developed that included several skills and 
knowledge aspects. The eight areas and the lean knowledge aspects are summarized here with the literature source:

\section{STANDARDIZATION (TEZEL 2011)}

- Keep only needed tools, materials and resources in the work area

- Put everything in its place and make a place for everything (use tape, outline areas, use peg boards)

- Mark the crane spots unloading bays, areas of work and the floor to highlight the walkways and location of tools and materials such that a safe and efficient working environment is established

- Color code the places by trade, traffic and material logistics plans

- Clean the tools and working areas when done or before

- Implement a task by following a standardized procedure

- Ensure, as a construction worker that you are following the standards through periodic self-evaluation

- Make shadow boards and use them to organize and ensure the availability of the tools

\section{Pull Production (Arbulu et al 2003)}

- Understand the sequence of tasks

- Realize the internal and the external customers of a process

- Provide the right products in the right place at the right time

- Make the processes transparent (Koskela 2000)

- Understand the types of flow: materials, information, crew, space,,,

- Understand and practice production-ordering- kanban and transport/ supplier kanban

- Know how to use kanban cards, a production leveling heijunka board, and in station quality (jidoka) via andon board(Tezel 2011)

\section{WASTE (OHNO 1988)}

- Understand and learn how to eliminate the types of wastes

- Avoid rework through using simple job aids such as checklists and standardized work plans

- Reduce unnecessary movement of workers on the construction site and unnecessary transportation of materials, equipment and tools

- Limit unnecessary processing of the work

- Understand and eliminate the making do waste which is starting a task without its standard inputs or the execution of a task is continued where one of its inputs has ceased (Koskela 2004) 
- Understand and eliminate the task diminishment waste which is executing a task in a way that doesn't comply with the specifications (Patton 2013)

- Understand and eliminate the defects produced from executing a task in the wrong way

- Simplify by minimizing the number of steps to perform a certain task

\section{KAIZEN (LIKER 2004)}

- Reflect upon the root causes of a problem and take preventive measures to avoid its occurrence in the future

- Practice kaizen everyday through every work procedure done

- Make reliable promises (Hamzeh 2011)

- Suggest new ideas about how to do individual work, to improve safety, product quality, productivity or quality of work life

- Donot hide problems (i.e. lower the river to reveal the rocks)

- Ensure working as a team (Hamzeh 2011)

- Ensure viewing the process and the result, not the result alone

- Respect everyone on the construction site

\section{Site Organization(Tezel 2011)}

- Ensure that flow paths of people are properly marked, unobstructed, paved, flagged, protected and empty

- Ensure a clean and organized site with signs: place for inventory, jobs, technical room, warehouse, cafeteria, floor numbers, self-explaining signs

- Dedicate clear areas with signs for materials

- Gather small parts orderly in bins and at locations close to utilization

- Use signs for the materials in the stock with their corresponding quantities for replenishment

\section{QUALITY (LIKER 2004)}

- Ensure quality right the first time even if it means to slow down or stop to enhance productivity on the long term

- Do in process-self inspection

- Ask 5 whys to understand the root causes of a problem

- Understand the regular quality control procedures for concrete, pouring ....

\section{Planning ANd Control: (Brady 2014)}

- Organize the daily work and put a plan to execute it

- Know the weekly work schedule 
- Get involved in the planning of the work and the daily huddle meetings by giving input, progress and problems while performing certain task

- Define and know the component of the product to be constructed as to content, timing, sequence, outcome, and describe the work to be done as shown in plans and specifications

To investigate the knowledge of construction workers in these categories, the authors carried out a survey. The questionnaire was pilot tested in order to evaluate the clarity of the survey questions and thus introduce corresponding adjustments. Then the survey was filled out during semi structured interviews with 73 construction workers on 7 different construction sites and with 7 different companies. The author ensured the anonymity of the respondents. The survey was printed in the local language of the construction workers for their ease of understanding and responding freely and honestly. The total number of questions of the survey was 42 distributed among the eight categories of lean construction. Respondents answered each question based on a Likert scale from 1 to 7 which expresses the degree of agreement with each statement where 1 represented "entirely disagree" and 7 represented "entirely agree".

\section{THE SURVEY TOOL}

The survey begins with a question regarding whether the respondent was a worker or a skilled worker and his/her years of experience. The respondents answered the statements based on the degree to which they agree on these statements and the degree to which they employ them in their usual daily work. The questionnaire started with an assurance regarding its confidentiality. The questions aimed to gather specific information about the way construction workers execute, and practice daily work, in addition to their indirect vision regarding lean construction concepts. As a result, the survey tried to indirectly assess the way construction workers executed their work in accordance to lean construction concepts, starting from kaizen, pull production, planning and control, waste, quality, safety, site organization, and standardization. The survey was based on the lean knowledge profile.

To collect the data, a structured face-to-face interview was performed on different construction sites in Lebanon. The construction site engineers were called and the authorization to access the construction site was given. In some cases, a previous meeting was scheduled with the project manager and the general foremen to introduce them to the survey. It is worth mentioning that several companies refused to take part in this study.

When on site, the first thing was to introduce the purpose of the study. All the questions were explained in order to avoid false results. On most construction sites, the construction workers were grouped in a room or in a small circle to complete the survey.

\section{DATA ANALYSIS AND DISCUSSIONS}

Each question in the survey was related to one of the eight categories of the lean construction knowledge. First these questions were organized per the eight categories, then the average score per category for each respondent was calculated.

A boxplot was generated based on the eight categories where K represents Kaizen, PC: Planning and Control, PP: Pull Production, Q: Quality, SA: Safety, SO: Site Organization, 
ST: Standardization, W: Waste. The boxplot confirmed that waste and pull production scored the worst categories among the others. In addition, Pull Production, Standardization, Site Organization and Quality scored a median very close to 4 . This shows that construction workers have little knowledge regarding these concepts. Kaizen scored high due to the bias in the responses of the construction workers. This type of bias is a response bias. Thus the respondents' answers in kaizen, which refers to continuous improvement, are biased toward what they believe is socially and ethically desirable: continuously improve and develop themselves. Construction workers have general idea about the importance of using helmets, and protective equipment, but this is not enough when it comes to international safety procedures on construction sites.

The respondent averages were statistically analyzed in order to establish if the eight categories were significantly different from each other. The non-parametric test KruskalWallis rank sum test was used. The null hypothesis was that there was no difference across the eight categories. The p-value obtained from the Kruskal- Wallis test is $2.895 \mathrm{e}-13$ which indicates that there is enough evidence to indicate that at least one of the eight categories was different from the others.

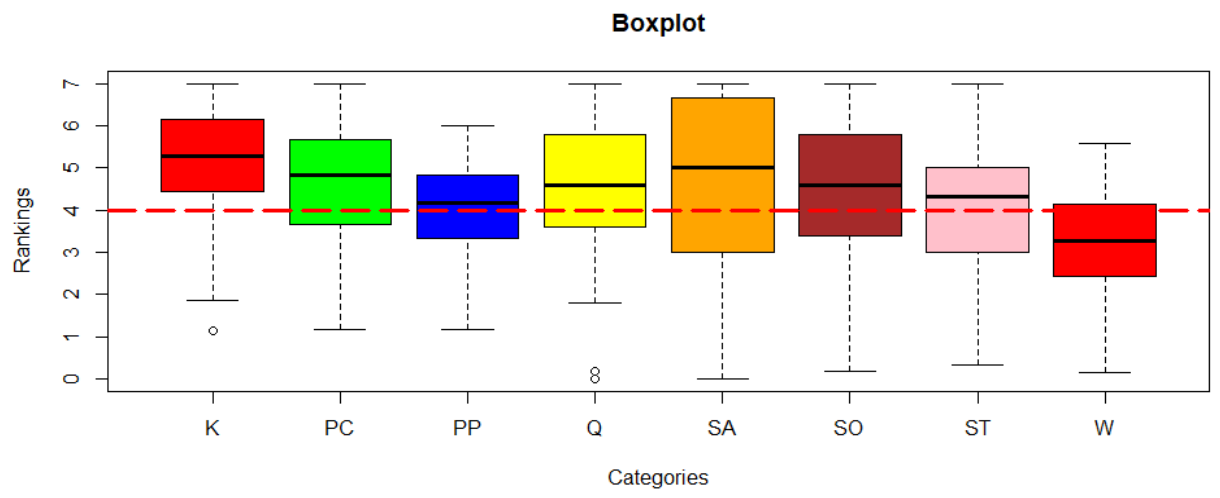

Figure 1: Boxplot for the Eight Categories of Lean Knowledge Profile

\section{OBSERVATIONS}

In this section, the authors discuss the observations encountered during the site visits. First, it was clearly observed that little-to no training is given for construction workers, where only engineers, foremen and general contractors are the center of the focus. There is a focus mainly on the training and development of engineers, project managers, and general foremen. For example: only general foremen on construction sites were trained to face safety-related procedures, such as: fire hazards, and given emergency response trainings.

Second, construction workers might have heard about safety practices, and the other lean concepts mainly from the implementation of ISO standards in certain companies. This explains the current limited knowledge regarding such practices. In addition, they might have heard of such practices from other construction sites and from the engineers on sites. But these safety standards are only the basics, for example, other safety regulations such as: working at heights and wearing high visibility jackets are being ignored. 


\section{RECOMMENDATIONS}

After analyzing the results of each question and the overall categories in the survey, the following recommendations were developed:

Since construction workers showed a lack of knowledge in the areas of waste and pull production, construction workers must receive training in all categories of lean construction, with strong emphasis on those two categories. Training games demonstrate lean construction principles and concepts in action. Games allow construction workers to get involved and engaged in the learning process. Training games help construction workers implement their lean roles properly, understand the lean construction concepts, and fully integrate the lean construction knowledge profile. To develop an understanding of how lean conctrution games can address the seven categroies metioned in this study, the following procedure was followed:

- Different lean games that target lean manufacturing and lean construction were investigated. Out of these games only the ones that tackle lean construction were identified and in particular the ones that construction workers can relate to i.e. the ones which fall into the eight categories and the lean knowledge profile.

- The lean areas that every game address were identified. Then, each area was linked to the eight categories previously mentioned before.

- The table matches the games with the areas of weaknesses found in the study.

The selected games along with their corresponding contribution to lean construction concepts are given below in table 1 . They can be used by any construction project in the world to address the areas of weakness faced on the project.

Table 1: Suggested Lean games and the corresponding lean categories they address

\begin{tabular}{|c|c|c|c|c|c|c|c|}
\hline Games & $\begin{array}{c}\text { Site } \\
\text { Organization }\end{array}$ & Waste & Kaizen & Standardization & $\begin{array}{c}\text { Pull } \\
\text { Production }\end{array}$ & $\begin{array}{c}\text { Planning and } \\
\text { Control }\end{array}$ & $\begin{array}{c}\text { Qualit } \\
\mathrm{y}\end{array}$ \\
\hline $\begin{array}{c}\text { House of Cards } \\
\text { Standard Pig } \\
\text { Game }\end{array}$ & $\mathrm{X}$ & $\mathrm{X}$ & $\mathrm{X}$ & & $\mathrm{X}$ & $\mathrm{X}$ & \\
\hline 5s Numbers & $\mathrm{X}$ & $\mathrm{X}$ & $\mathrm{X}$ & $\mathrm{X}$ & & & $\mathrm{X}$ \\
\hline Ball Game & $\mathrm{X}$ & & $\mathrm{X}$ & & & & \\
\hline Dollar Game & & & $\mathrm{X}$ & & $\mathrm{X}$ & & \\
\hline
\end{tabular}




\begin{tabular}{|c|c|c|c|c|c|c|}
\hline Broken Squares & & $\mathrm{X}$ & & & $\mathrm{X}$ & \\
\hline Leapcon & $\mathrm{X}$ & & $\mathrm{X}$ & $\mathrm{X}$ & & \\
\hline Parade Game & & & & $\mathrm{X}$ & & \\
\hline Airplane Game & & $X$ & $\mathrm{X}$ & $X$ & $\mathrm{X}$ & $\mathrm{X}$ \\
\hline $\begin{array}{l}\text { Maroon White } \\
\text { Game }\end{array}$ & & $\mathrm{X}$ & & & $\mathrm{X}$ & $\mathrm{X}$ \\
\hline Dice Game & & & & X & $\mathrm{X}$ & \\
\hline $\begin{array}{c}\text { Win As Much As } \\
\text { You Can }\end{array}$ & & $\mathrm{X}$ & & $\mathrm{X}$ & $\mathrm{X}$ & \\
\hline Villego & & $\mathrm{X}$ & $\mathrm{X}$ & X & $\mathrm{X}$ & \\
\hline Lebsco & & $X$ & $\mathrm{X}$ & $X$ & $\mathrm{X}$ & \\
\hline $\begin{array}{c}\text { Marshmallow } \\
\text { Simulation }\end{array}$ & & $\mathrm{X}$ & & & & \\
\hline $\begin{array}{l}\text { Deming's Red } \\
\text { Bead Game }\end{array}$ & & & & $X$ & $\mathrm{X}$ & $\mathrm{X}$ \\
\hline $\begin{array}{l}\text { Paper Airplane } \\
\text { Game }\end{array}$ & & & & $\mathrm{X}$ & & $\mathrm{X}$ \\
\hline $\begin{array}{l}\text { Helium Stick } \\
\text { Game }\end{array}$ & & $X$ & & & & \\
\hline $\begin{array}{c}\text { Pipes and } \\
\text { Marbles }\end{array}$ & & $\mathrm{X}$ & & & & \\
\hline $\begin{array}{c}\text { Binniger's Takt } \\
\text { Game }\end{array}$ & $\mathrm{X}$ & & & $\mathrm{X}$ & & \\
\hline InFrame & $\mathrm{X}$ & $X$ & & $X$ & & \\
\hline $\begin{array}{l}\text { Last planner } \\
\text { Driven Game }\end{array}$ & & $\mathrm{X}$ & $\mathrm{X}$ & $\mathrm{X}$ & $\mathrm{X}$ & $\mathrm{X}$ \\
\hline $\begin{array}{l}\text { Lean Apartment } \\
\text { Simulation Game }\end{array}$ & $X$ & & & $X$ & & \\
\hline $\begin{array}{c}\text { Lean Cups } \\
\text { Game/ Dot Game }\end{array}$ & & & & $\mathrm{X}$ & & \\
\hline Make a Card & & & & $\mathrm{X}$ & & \\
\hline $\begin{array}{l}\text { Kanban pizza } \\
\text { Game }\end{array}$ & & & & $X$ & $\mathrm{X}$ & \\
\hline $\begin{array}{l}\text { Marshmallow } \\
\text { TVD Game }\end{array}$ & & $\mathrm{X}$ & & & & \\
\hline $\begin{array}{l}\text { Delta Design } \\
\text { Game }\end{array}$ & & $X$ & & & & \\
\hline Lego Game & & $\mathrm{X}$ & & $X$ & & \\
\hline $\begin{array}{l}\text { The Lean } \\
\text { Lemonade } \\
\text { Tycoon } 2\end{array}$ & & $X$ & & $\mathrm{X}$ & & \\
\hline
\end{tabular}

\section{CONCLUSIONS}

One of the pillars of lean construction is developing people and partners. Involving all the personnel on and off the construction site is vital for harnessing the full benefits of lean, and these personnel need to be trained on lean construction principles. Lean construction induces new roles, responsibilities and knowledge for construction workers. The authors identified eight main categories that construction workers should know, understand, and practice on the construction site, which are: pull production, planning and control, site organization, safety, quality, standardization, kaizen and waste. Based on these categories, 
a detailed lean construction worker knowledge profile was developed and tested. The main focus of this study was to develop a tool to assess and enhance the workers understanding of lean concepts. The assessment was made through a survey tool conducted on several construction sites in Lebanon. After analyzing the results of the questionnaire, the authors concluded that construction workers have a general lack of knowledge regarding the lean construction knowledge profile. The following results were obtained:

Construction workers have a lack of understanding and applying waste related concepts and their types, an absence of knowledge in lean pull production practices, and a general lack of understanding of site organization and standardization concepts. Construction workers are not strong believers of these concepts. They may support them but they donot strongly believe or understand the importance of applying them. These weakness are somehow related to the overall organization/ company's application of lean construction concepts, principles and practices.

Construction workers are not engaged in the planning and control of the construction activities on the construction site. They donot give feedback on the progress of their work. This is found when applying traditional construction methods that are still the norm on many construction sites in Lebanon.

\section{REFERENCES}

Alarcon, L. \&. (1999). Playing Games: Evaluating the Impact of Lean Production Strategies on Project Cost and Schedule. Proceedings of IGLC-7 (pp. 263-274). Berkeley, CA, USA: University of California, Berkeley, CA, USA.

Arbulu, R. J., Ballard, G., and Harper, N. (2003). Kanban in construction. Proc. 11th Ann. Conf. of the Intl. Group for Lean Constr. (IGLC-11), Elsinore, Denmark.

Ballard, H. G. (2000). The last planner system of production control (Doctoral dissertation, University of Birmingham).

Barbosa, G., Andrade, F., Biotto, C., \& Mota, B. (2013). Implementing lean construction effectively in a year in a construction project. In Proceedings for the 21st Annual Conference of the International Group for Lean Construction, Fortaleza, Brazil (pp. 1017-1026).

Bernstein, H. M. \& Jones, S. A. (2013). Lean construction: Leveraging collaboration and advanced practices to increase project efficiency. Intelligence, McGraw Hill Construction, Bedford, MA.

Brady, D. A. (2014). Using visual management to improve transparency in planning and control in construction (Doctoral dissertation, University of Salford).

Brady, Denise Ann, Tzortzopoulos, Patricia and Rooke, John (2011). An examination of the barriers to last planner implementation. In: 19th Annual Conference for Lean Construction, 13-15th July 2011, Lima, Peru.

Guerrero, S. and Sire, B. (2001) "Motivation to train from the workers' perspective: example of French companies." International Journal of Human Resource Management, 12 (6), 998-1004.

Hamzeh, F. R. (2011). The lean journey: implementing the last planner system in construction. In Proceedings of the 19th Annual Conference of the International Group for Lean Construction, Lima, Peru, pp. 379-390. 
Hamzeh, F. R. (2016). Using Forums and Simulation Exercises to Enhance Active Learning in Lean Construction Education. Ch. 6. In R. N. Nasser, \& M. Romanowski, Social Justice and the Engineering Profession: Challenging Engineering Education to Move beyond the Technical (pp. 139-159). Springer, Cham.

Holt, J. (2012, April 23). Dollar Game. Retrieved 1 19, 2019, from kaizenworld: https://www.kaizenworld.com/kaizen-links/lean-games/dollar-game.html

JIT Flow Simulation AKA: The "Paper Airplane" Exercise. (n.d.). Retrieved 1 19, 2019, from Lean Australia: http://leanaust.com/wp-content/uploads/2013/04/JIT-FlowSimulation-Paper-Airplane-Simulation-Messier-Dowty.pdf

Koskela, L. (1992). Application of the new production philosophy to construction (No. 72). Stanford, CA: Stanford University.

Koskela, L. (2000), an exploration towards a Production Theory and Its Application to Construction, VTT Technical Research Center of Finland.

Koskela, L. (2004). Making do - the eighth category of waste. In Proceedings of the 12th annual conference of the International Group for Lean Construction.

Lambrecht, M. e. (2012). Extending the Production Dice Game. International Journal of Operations \& Production Management , 1460-1472.

Lean Enterprise Institute. (n.d.). Retrieved 1 19, 2019, from Lean.com: https://www.lean.org/FuseTalk/Forum/Attachments/5S\%20GAME.PPT

Liker, J.K. (2004). The Toyota Way- 14 Management Principles from the World's Greatest Manufacturer. New York: McGraw Hill.

Ohio State University. (2000). Broken squares. Retrieved 1 19, 2019, from Hunter College:http://www.hunter.cuny.edu/socwork/nrcfcpp/pass/learningcircles/five/Brokensquares.pdf

Ohno, T. (1988). Toyota production system: beyond large-scale production. crc Press.

Patton, J. R. (2013) Task Diminishment: Construction Value Loss due to Sub-optimal Task Execution. A Dissertation Presented to The College of Graduate and Professional Studies, Department of Technology, Indiana State University, in Partial Fulfilment of the Requirements for the Degree Doctor of Philosophy.

Pollesch, P. R. (2017). House of Cards - a Simulation of Lean Construction Principles. Proceedings of the 25th Annual Conference of the International Group for Lean Construction (IGLC), (pp. 373-380). Heraklion, Greece.

Red Bead Game. (2006, 8). Retrieved 1 19, 2019, from National Quality Center: nationalqualitycenter.org/files/nqc-game-guide-chapters/01-red-bead-game/

Rhemare source center. (2010, 9 29). The Ball Game - A Creative Team Building Exercise. Retrieved 1 19, 2019, from you tube: https://www.youtube.com/watch?v=rva3wRvpS_4

Rybkowski, Z. K. (2008). Using Controlled Experiments to Calibrate Computer Models: The Airplane Game as a Lean Simulation Exercise. Proceedings 16th Annual Conference of the International Group for Lean Construction (pp. 309-319). Manchester, England: University of Salford.

Sacks, R. A. (2007). LEAPCON: Simulation of Lean Construction of High-Rise Apartment Buildings. Journal of Construction Engineering and Management, 529-539. 
Shmula. (2013, 11 6). Standard Pig Game. Retrieved 1 19, 2019, from shmula.com: https://www.shmula.com/standard-pig-game/12385/

Sime, A. (2013, 9 5). Lean Games "Pipes and Marbles". Retrieved 1 19, 2019, from YouTube: https://www.youtube.com/watch?v=mYbEpJZA-Os

Smith, J. P., \& Rybkowski, Z. K. (2013). The Maroon-White Game: A Simulation of Trust and Long-Term Gains and Losses. 21st Annual Conference of the International Group for Lean Construction, (pp. 987-996). Fortaleza, Brazil.

Tezel, A. (2011). Visual Management: an exploration of the concept of and its implementation in construction. PhD, University of Salford.

The Dot Game. (2009). Retrieved 1 19, 2019, from net objectives: https://www.netobjectives.com/system/files/DotGame_vas11_0.pdf

The works manager. (2011, 9 13). Helium Stick. Retrieved 1 19, 2019, from YouTube: https://www.youtube.com/watch?v=RXI-C4jQXVk

Tommelein, I. D. (1999). Parade Game: Impact of Work Flow Variability on Trade Performance. Journal of Construction Engineering and Management, 304-310.

Tsao, C. C., Alves, T., \& Mitropoulos, P. (2012, July). Different perspectives on teaching lean construction. In Proc. IGLC (Vol. 20).

Villego the last planner simulation. (n.d.). Retrieved 1 19, 2019, from villego: https://www.villego.com/

Win as much as you can. (n.d.). Retrieved 1 19, 2019, from pi beta phi: https://www.pibetaphi.org/pibetaphi/uploadedFiles/Leading_with_Values/Win\%20as $\% 20 \mathrm{Much} \% 20$ as\%20You\%20Can.pdf

Wujec, T. (2010, 4 22). Tom Wujec: Build a tower, build a team. Retrieved 1 19, 2019, from YouTube: https://www.youtube.com/watch?v=H0_yKBitO8M

Zanotti, N.L. et al. 2017, 'Bottom-up Strategy for Lean Construction on Site Implementation' In:, 25th Annual Conference of the International Group for Lean Construction. Heraklion, Greece, 9-12 Jul 2017. pp 325-331 
Hamzeh, F.R, and Albanna, R.M

Proceedings IGLC-27, July 2019, Dublin, Ireland 